\title{
Unas palabras para descorrer la Bruma*
}

\author{
A few words to draw back the mist
}

\author{
WALDO ROJAS \\ (Panthéon Sorbonne). \\ waldo.rojas@free.fr
}

Ancien Maître de Conférences à l'UFR d'Histoire Université de Paris I

T a presentación de un libro se ha vuelto en el marco de la sociabilidad Cliteraria chilena un rito sin misterio, cuyos códigos ceremoniales, debo admitir, no me resultan aún lo suficientemente quitados de brumas, pese a mi propia experiencia repetida de simple número en medio de los asistentes ordinarios a estas ceremonias. Pero hasta donde nuestro modo de ver nos hace ver claro, de lo que se trata en resumidas cuentas es de hacer extensiva a un público, por el momento auditor, y como esperamos, pronto lector, la invitación que nos hiciera tácitamente el autor, en este caso la poeta María Inés Zaldívar, al confiarnos su reciente libro para una lectura personal.

Por "una lectura personal" queremos referir aquella de uso personal, íntimo, en cierto modo y que consistiría no ya en buscar satisfacer en la frecuentación de un poemario ajeno unas respuestas a nuestras preguntas más tenaces sobre lo que es un poema, sino, muy por el contrario, en indagar ahí, justamente, la posibilidad de esas y nuevas preguntas.

Según este modo de ver las cosas, los primeros signos de una intención significativa en poesía -o dicho de otro modo, de un trabajo poéticamente genuino- aparecen cuando su lectura nos conduce una vez más a interrogarnos, como en el primer día, sobre lo que puede ser la poesía. Es decir, sobre su diferencia significativa respecto de toda otra construcción verbal, a cuyo conjunto llamaremos, por ejemplo, prosa, pero que podría llamarse

\footnotetext{
* Texto de presentación del libro Bruma, de María Inés Zaldívar, en la Biblioteca del Centro Cultural Gabriela Mistral de Santiago, Chile, el 14 de noviembre de 2012.
} 
también lenguaje de uso doméstico. Aparte la seguidilla de innumerables interrogaciones obvias, hay una o dos que siéndolo un poco menos guardan siempre su pertinencia.

¿Es el reemplazo, consciente o no, por el poeta, de la comunicación llana por la simple sugerencia? ¿O por la sobrecarga de imágenes, figuras, tropos, etc., esos intríngulis o galimatías que descorazonan la lectura gallardamente dispuesta del común de los mortales?

¿O se trata tal vez de un discurso perdulario que con desmaño pierde de vista las fronteras de los géneros tan celosamente trazadas por la academia, de Aristóteles a nuestros días? ¿Es una tentativa de arrancar esos maravillosos objetos que son las palabras a su ancestral dependencia de la razón? Y si el decir del poema - puesto que de todos modos un poema es un decir- no quiere ya decir la razón, ¿qué es lo que nos dice? ¿A quién, o a qué el poema da la palabra? ¿Y con qué derecho da algo que su propio acto de decir inutiliza para los fines habituales de la palabra al volverla incierta? O, finalmente, con toda la salvedad del caso, ¿sería el poema, concebido como está, el espacio privilegiado de la mirada que el lenguaje vuelve sobre sí mismo? Basta que a la lectura de un poemario broten estas preguntas para caer en el anuncio de que lo que leemos son efectivamente poemas, porque de todo ello hay en el acopio de la verdadera poesía. Y que cada poeta encuentre sus intransferibles respuestas.

Desde ya la presente publicación escapa por su puesta en página a una edición habitual de un libro de poemas. La autora ha querido incluir en su configuración gráfica una serie de piezas fotográficas confrontadas a sus textos y sin mayor comento que el nombre del fotógrafo, Bruno Ollivier. Son éstas en su mayoría unas vistas de ceñido recuadro que eluden las más veces la presencia de seres animados, o los sugieren, en favor de objetos o parajes, o huellas perceptibles de vidas invisibles.

Un libro, ya sabemos, no se reduce a sus páginas interiores, poco importa el contenido de éstas. Su título inscrito en la portada, la portada misma en su concepto gráfico, sus elementos de información sobre la identidad del autor contenidos habitualmente en la solapa, las circunstancias de la edición, etc., amén de eventuales prefacios o simplemente epígrafes, o sea sus paratextos, como dicen los especialistas, son otros tantos factores que inciden en la circunstancia de su lectura.

Valga advertir, de paso, que al título propiamente tal de estos poemas precede la mención genérica de "Canto", y cabe preguntarse si no juega aquí un vago sesgo paródico visto que, como se sabe, de Homero a Darío, se designa especialmente como canto aquella composición poética de tema 
elevado y tono solemne. Ahora, salvo alguna excepción, como es la del Canto IX, titulado "Mar adentro", los poemas de Bruma, como veremos, se atienen, por el contrario, a una prosodia de sobria hechura y su vocabulario incurre con llaneza en giros o vocablos de temple coloquial e incluso de corte idioléctico.

Un libro, y sobre todo un libro de poemas, huelga insistir en ello, sólo existe en y por su lectura, sus lecturas, en la apertura que es lo propio de éstas, a lo cual contribuirá en gran medida, en tanto contexto inmediato, la compaginación y todo cuanto se juega en ella.

En este nuevo poemario de María Inés Zaldívar, nos parece, el advertido lector deberá abstenerse de ver una serie de poemas ilustrados por otras tantas vistas fotográficas, como también de no ver aquí sino unos textos suscitados por el poder sugestivo de unas fotografías de arte. Una tal lectura pasaría al lado de la novedad y el interés de esta obra singular. La historia de sus páginas que así confrontan poemas y fotografías es la de un encuentro sin cita concertada. Historia de un hallazgo mutuo; los unos y las otras, cada cual con sus notables calidades, estaban ahí, desde tiempos y horizontes distintos, y desde sus respectivos vértices de apertura vueltos hacia la eventualidad de una experiencia in-nombrada: experiencia de lectura que inventa su condición de posibilidad. Bien visto, lo común entre los 24 poemas y el mismo número de imágenes fotográficas es que ambos conjuntos responden a tópicos y temas igualmente heterogéneos.

Como es lo propio de toda fotografía, la imagen objetiva captada por la cámara se cumple en la paradoja de hacer que el mundo se desvele a sí mismo habiendo disuelto la realidad de éste, con la cual ella sin embargo coincide punto por punto. Puesto que su reproducción de ese mundo, siendo exacta es mecánica por necesidad. Es sabido que apenas si se puede hablar de "imagen" a propósito de la fotografía, puesto que conteniendo todos los significados no retiene ninguno. Hablando como habla para nadie, la foto ni siquiera habla para el fotógrafo: una vez disparado el objetivo, todo ha terminado y el fotógrafo ya no tiene influencia sobre su motivo. En el chispazo de sus imágenes, por el contrario, el poema habla para nosotros y nos retiene en el "territorio del sentido" ( $V$. Canto $\mathrm{XX}$ ); en sus imágenes imita al mundo transfigurándolo y, permaneciendo por ello en esencia y materia distinto de él, congrega su mirada impregnada de humana intimidad. Sólo que, como no faltará probablemente de hacérnoslo notar, se trata aquí, con evidencia palmaria, de un trabajo de "fotografía artística", es decir, de un intento tan legítimo como el del poeta, de humanizar la imagen ordenando como un lenguaje la potencia objetivadora del mundo fotografiado. Cual- 
quiera sea su resultado estético, el fotógrafo permanecerá dentro de los límites hechiceros de ese mundo objetivo re-producido ya que no re-presentado.

Se suele asociar el poema a la fotografía en virtud de un cierto poder de evocación, y es así que se habla de la imagen-símbolo; pero a pesar del sentido, metafórico, que se le confiere, tal imagen no remite más que a la verdad de su propia apariencia. Una imagen del mar, por ejemplo, rompiendo sobre las rocas de la costa - un poco como la foto que acompaña el citado poema "Chascona" del Canto XX- no es tanto el símbolo de las pasiones, sino la realidad evocada de las pasiones que viene a reforzar ese decir simple e intransferible del mar por el mar. No es tanto la naturaleza que se humaniza como el universo moral que, por así decir, se mundaniza.

Un sintagma simple, en cambio, en el cuerpo de un poema, que la intuición del poeta, fuera de toda receta, se ve consciente o inconscientemente impelido de privar de contexto, basta y sobra a menudo, para aquel efecto; como por ejemplo aquí, en el Canto XIX, el verso de "...la deseada brasa".

Lo que la poesía no comparte con las otras formas de arte, en este caso justamente el arte fotográfico, es su materia, o sea la lengua. Decir que esta materia es su instrumento no es ni suficiente ni veraz, pues la lengua es en verdad su todo. La poesía restituye a la lengua su superioridad sobre lo real o lo irreal que ella designa o connota. Es mediante el lenguaje que el poeta funda esta superioridad: la cruel ironía consiste en que su tarea estriba en no admitir nunca que la lengua se esfume en el mundo que ella designa; el instrumento es la lengua, aquélla con la cual compramos el periódico, que en sí mismo está plagado de lengua (y cuánto más de... ¡fotografías!) (Dejaremos pernoctar este asunto, que de todos modos quisiéramos despertar alguna mañana acerca justamente de su pertinencia puntual con la poesía).

El hecho es que el título de Bruma, así, en singular, nos llamó la atención no sin razones. En sus poemarios anteriores María Inés Zaldívar manifestaba un interés particular por la elaboración de los títulos. Artes y oficios (1996) y Ojos que no ven (2001), por ejemplo, remiten a juegos de paráfrasis sobre expresiones del lenguaje corriente, e implican en ello una distancia tomada con la solemnidad. De otro modo, Naranjas de medianoche (2006) y Luna en Capricornio (2010), ya menos denotativos en su fórmula figurativa, van en el sentido de una clave emocional, a la cual podemos asimilar el presente título de Bruma, confirmando de paso la ausencia de gratuidad en la elección de dichas rotulaciones.

Un título en la portada, decíamos, incide en la lectura de todos o de cada uno de sus textos, denotativa o connotativamente. Es una manera de "hacer sentido" y, como se ha dicho, el mejor aliado al mismo tiempo que el 
más temible enemigo de la poesía es el imperativo de "hacer sentido", sobre todo cuando se busca hacerlo para salir del paso. Se ha dicho también que del mismo modo como la gran duquesa no soportaba el té chino, la especie humana no soporta el vacío de sentido (aunque para T. S. Eliot lo insoportable fuera el "exceso de realidad"...). No hace falta tratar de decir algo, el texto se encargará de ello. El término "Bruma" nos llamó, pues, la atención, precisamente por "hacer sentido".

Dicho término remite por supuesto a aquella multitud de infimísimas gotitas de agua en suspensión en el aire, que enmascaran de modo más o menos opaco el cielo, la superficie del suelo o de las aguas. La fotografía que acompaña uno de los poemas, así como otras dos que abren y cierran respectivamente el libro, objetivan diversamente este sentido. Es uno de esos términos que, en plural, la lengua literaria ha terminado por cargar (iba a escribir: por "abrumar"...) de sentidos figurados: brumas del corazón, del espíritu, del alma, de la razón, o del destino, alejándolo en el uso de su sinónimo cotidiano y trivial de 'niebla' o 'neblina'. En otro orden de consideraciones, el vocablo es un empréstito del latín clásico, que designaba el día del año más corto del solsticio de invierno, o el solsticio de invierno mismo -el de diciembre en el hemisferio norte y de junio en el hemisferio sur-, y por asimilación, la época de fríos invernales.

Algo de aquellos sentidos figurados que inducen en el ánimo un humor de melancolía, nostalgia, añoranza vagamente aflictiva como sería aquélla inscrita en ese lírico "recordar el olvido", de que nos hablan los versos del Canto XIX ("Río"), y que se ha querido verter sobre el conjunto de los textos:

\section{Si recuerdo el olvido}

en vez de la memoria

rescato la ilusión de una luz perdida.

No obstante, el vocablo "bruma" aparece sólo en uno de los primeros poemas del libro (Canto XV) y es este texto, justamente, que prefigurando a modo de referente, bajo el título de "Hay revolución", un estado de cosas que multiplica los signos de un vaticinio calamitoso, se presenta perlado de giros antilíricos, se puede decir, y de registros de la verba coloquial:

\section{(...) Se agotan ansioliticos, antidepresivos}

tragan analgésicos, sedantes e hipnóticos

incluso antiespasmódicos y relajantes musculares 
La población arrasa la hierba de san Juan, se consumen litros de agua de Melisa (...)

No hay tutía para heridas sálvese quien pueda, dicen La ciudad respira cansada A bordo nadie sabe la firme

Permanece el silencio

Una extensa bruma cubre la faz de la Tierra (...).

Otro modo de hacer sentido aquí, y que iría en la orientación del humor melancólico ya señalado, concierne, sin duda, a los tres epígrafes inscritos en el pórtico del libro. Tres poetas japoneses venidos de varios siglos precedentes y celebrados como precursores o célebres maestros del hä̈ú, término para designar esta modalidad poética japonesa, que fuera creado y adoptado hacia fines del siglo XIX, y ella misma sólo difundida en Occidente desde comienzos del XX. El haïkú, como se sabe, es ese poema extremadamente breve que apunta a decir la evanescencia de las cosas del mundo. Así reza el primero de estos epígrafes:

Fue darme vuelta

y el hombre que cruzaba

se hizo niebla

Masaoka Shiki (Japón 1867-1902).

No se nos escapa, en esta captura de sentidos, que uno de los últimos textos, el Canto XXII, titulado "Anuncio", incorpora en su primer verso al flautista Tammuz, personaje venido del mito sumerio/acádico, a menudo desenterrado en nuestros días por el así llamado "paganismo moderno", y que narra el descenso al Inframundo de su amante, la Diosa de la fertilidad Ishtar. Ahora bien, dicha divinidad pagana retorna desde el Inframundo en la celebración del Solsticio de Invierno, o dicho de otro modo, en la época llamada otrora Bruma, cerrando así el círculo abierto por el título del libro: "Otra vez el flautista Tammuz - dice este poema- sopla y renace la primavera".

La mención, verso seguido, del nombre de Ulises, figura imaginaria y estrechamente asociada al Mar, ha llegado a ser, por lo demás, al cabo de los siglos, si faltare recordarlo, uno de los más arraigados tópicos del habla corriente para aludir al motivo del Viaje. El largo viaje de improbable peripecia al cual se funde, entre otras figuraciones emblemáticas, nuestra trayectoria sublunar. $\mathrm{Y}$ a este nombre se hallan atraídos, y están aquí aludidos 
o esbozados, los de Telémaco, Itaca, Polifemo o Tiresias, Circe o Calipso, el pueblo de los legendarios Feacios y otros Aqueos o Troyanos... Y, por cierto, el nombre de Penélope, la esposa inagotablemente fiel, alter-ego huidizo de la hablante de buena parte, si no, de modo diverso, de todos los poemas; una hablante que tal vez en su discurso se afana como aquella figura ancestral, voluntariamente o no, conscientemente o no, en deshacer su propio tejido, o sea, su texto:

(...) Sobre la superficie lisa de madera dentro del pequeño cuarto semioscuro garrapatea signos sobre una hoja de papel

Son breves palabras sin sentido confusas señales que flotan en la página como ansiosos peces en busca de alimento (...) [Canto IX, "Mar adentro"]

Este mar no es, claro está, ese mar que mece la mirada o acuna el ensueño, sino aquel que aleja y separa corazones y cuerpos: "Esposa, hijos y amigos, lejos / (...) olas, viento y recuerdos".

Podemos ver también que la figuración viajera del Ulises así comprendida se reencarna asimismo, con otra significación, en un personaje del filme británico La misión, un cazador de indios guaraníes y protagonista emblemático, más tarde, de un atribulado viaje de redención física y psicológica, si no moral y hasta política: se trata del capitán español Rodrigo Mendoza que, brevemente aludido, tematiza el Canto XXI, titulado no por nada "Mochila", ese atuendo o apero por antonomasia de viajeros.

En el conjunto de todas estas reencarnaciones y resurrecciones metafóricas el mito es reescrito y se remotiva con guiño irónico en la inserción de objetos y usos de la modernidad actual, actuante, de la globalización, a fuer de un despliegue léxico que va de "buses y luces" al "antifaz de la aerolínea, los "somníferos de última generación" y la, "batería" descargada del teléfono en la "la habitación del hotel" dotada de "microondas", pasando por "llaves de un automóvil arrendado", "cupos" de aerolíneas y artículos mercantiles "Ted Lapidus (made in China, of course)" y otro "labial Chocolate Ice, (que) está agotado, (y) desapareció, / como Ulises".

Si entendemos por "motivo" una tela de fondo, un concepto vasto que designa una cierta actitud o una situación de base, impersonal, cuyos actores no han sido necesariamente, o no siempre, individualizados, el Viaje es justamente el trasfondo o motivo dominante de Bruma, en la constancia y 
profusión de sus signos alusivos. No ya, como el lector advertirá de temprano en su lectura, a cuento del placer de la ruta, con su recompensa de encuentros y alegrías insospechadas, sino en su plasmación del Desencuentro, el de sí mismo tanto como el desencuentro del Otro, "en el surco del sendero / que Venus dejó en mi destino" (Canto XVII, "Guarida"). Motivo de la soledad movediza del Viajero ("Ulises está solo, está lejos", dice el Canto XXI), de sus encrucijadas giratorias, en "la vuelta de la esquina sin encuentros", de que habla el último verso del libro.

Las fotografías de Bruno Ollivier, decíamos, no hablan de los textos, o casi no lo hacen, agregaríamos ahora, ni éstos de las fotografías. Sin embargo, en el concepto gráfico del libro dos paisajes embozados de brumas, ambos desplegados en doble página, al comienzo y al final, respectivamente, dialogan entre ellos. Y lo hacen sin palabras, o tal vez con todas las palabras juntas de este poemario, para abrir y cerrar también el círculo del que hacíamos mención a propósito del fenómeno atmosférico, por un lado, y por otro de la etimología del término que intitula la obra, es decir, el solsticio de invierno al que también remite Ishtar, la amante del flautista Tammuz. El primer paisaje muestra la cerrazón de troncos y ramas a media altura tras la espesa bruma. En el segundo, en la vastedad del bosque se ve brillar, no muy lejos, un punto luminoso clavado en el trasfondo embrumecido: ¿es el signo del rescate de "la ilusión de una luz perdida"?... 